Article

\title{
Evaluating the Ecological Services of Roof Greening Plants in Beijing Based on Functional Traits
}

\author{
Yuhong Tian ${ }^{1, *}$, Fangshu Zhao ${ }^{1}$, Tiantian Wang ${ }^{1}$, C.Y. Jim ${ }^{2} \mathbb{E}$, Taoran $\mathrm{Xu}^{1}$ and Jianjun Jin ${ }^{1}$ \\ 1 State Key Laboratory of Earth Surface Processes and Resource Ecology, Faculty of Geographical Science, \\ Beijing Normal University, Beijing 100875, China; fzhao@mail.bnu.edu.cn (F.Z.); \\ 201821051150@mail.bnu.edu.cn (T.W.); nishikido_66@163.com (T.X.); jjjin@bnu.edu.cn (J.J.) \\ 2 Department of Social Sciences, Education University of Hong Kong, Hong Kong, China; cyjim@eduhk.hk \\ * Correspondence: tianyuhong@bnu.edu.cn; Tel.: +86-010-5880-0198
}

Received: 16 May 2019; Accepted: 11 September 2019; Published: 26 September 2019

\begin{abstract}
Selecting suitable species to enhance ecological functions is crucial for improvements in the planning and design of roof greening and in maintaining sustainable urban development, especially in rapidly urbanized areas. Assisted by field trips to enhance studies, the present project assessed the ecological functions of 207 plant species used for roof greening in Beijing based on their key functional traits. The results indicate that regulating, cultural, supplying, and supporting functions differed significantly among species and families in the study area. Rosaceae species have higher levels of overall ecological functions than other species, and a large number of Compositae species have lower-level functions. Compared to other families, Araliaceae and Nyctaginaceae have higher mean values of cultural and supporting functions and the highest mean overall function value of 37 . Ulmaceae, Sapindaceae, Ginkgoaceae, Berberidaceae, and Aceraceae have higher mean regulating, cultural, supporting, and overall function values. Amaranthaceae, Umbelliferae, Lamiaceae, Saxifragaceae, Ericaceae, and Gramineae have lower values. The existing roof greening in Beijing includes some pitfalls with respect to plant composition as well as plant selection that does not consider ecological functions. The following measures could be proposed to increase ecological functions: (1) Increasing the number of plants with shallow roots and with strong adaptation traits to roof conditions; (2) Enriching ecological communities with diverse plants with high ecological functions; and (3) Carrying out rational ecological planning and management based on detailed and objective data on plant species. Future studies should focus on specifying plant functional traits to enhance ecological functions.
\end{abstract}

Keywords: plant functional traits; ecological function; roof greening; rapidly urbanized area

\section{Introduction}

Roof greening refers to planting on top of buildings or on elevated platform areas including roofs, terraces, and podiums, as well as on aerial platforms and overpasses that are not directly connected to natural soil on the ground [1]. It is usually divided into three categories: extensive, semi-extensive, and intensive [2,3]. Extensive green roofs have a characteristic shallow substrate of $<15 \mathrm{~cm}$ in depth, and are usually covered with herbaceous or low-shrub plants that are tolerant to environmental stresses, tolerant to mowing or pruning, demand little or no irrigation, and require little maintenance. Intensive green roofs integrate green function and leisure function as a whole. Their substrate is deep and they can support woody plants including trees and shrubs accompanied by herbaceous ground-level vegetation, most of which is ornamental [4]. Semi-extensive green roofs have characteristics lying between the above two categories, and may offer a combination of environmental and aesthetic benefits [5]. 
Green roofs can supplement the ground-level greening space and provide urban ecological functions, especially in high-density urban areas [6]. The ecological functions of roof greening refer to the ability of the roof greening ecosystem to provide material products, ecological public welfare, environmental resources, and aesthetic value to enrich outdoor recreational opportunities and quality of life [7]. The ecological functions provided by roof greening can be summarized through four types based on a four-point method for the classification of ecosystem services [8]. Firstly, regulating functions include regulating ambient temperature and humidity [9-12], mitigating air pollution [13], conserving water $[7,14,15]$, and abating noise pollution [16]. Secondly, cultural functions include landscape services, recreational services, spiritual services, etc. Thirdly, supporting functions include nutrient cycles and providing habitats for wildlife $[17,18]$. Fourthly, supplying functions include medicinal, edible [19], fodder, landscape, economic [20], and nutritional [21] value.

Plant functional traits, such as plant life form, plant height, life-span, and regeneration pathways, refer to a series of plant attributes closely related to planting, survival, growth, and reproduction [22,23]. Four kinds of functional trait classification systems are widely used at present, including: (1) the functional trait system that responds to disturbances on a global scale for herbaceous plants proposed by McIntyre et al. [24]; (2) the morphological and life-history trait system for temperate zone woody plants proposed by Mabry et al. [25]; (3) the handbook of standardization and simple measurement procedures for plant functional traits worldwide by Cornelissen et al. [26]; and (4) the classification system of plant traits in the Mediterranean region proposed by Barboni et al. [27]. Such systems focus on the relationships among plant functional traits, environment, and ecological contributions.

Plant functional traits reflect the distribution and utilization of light, temperature, nutrients, water, and other resources [26,28-30]. Different plants have different permutations of functional traits. They exhibit a variety of strategies to acquire, leverage, and provide resources, and to increase the diversity of the ecosystem and the stability of ecological systems [31,32]. Firstly, there are environmental regulating functions: plant growth form, leaf texture, leaf shape, and leaf size can influence ambient temperature and humidity, alleviate air pollution, conserve water, and reduce noise pollution $[7,33,34]$. Secondly, there are landscape-cultural functions: foliage and ornamental plants cultivated in roof greening can create a unique roof landscape and endow the site with cultural aesthetic, recreational, and spiritual value. Thirdly, there are wildlife-supporting functions. Roof greening can provide forage, shelter, and habitats for wildlife [18], and safeguard the normal operation of ecological processes such as energy flow and nutrient cycling. Fourthly, there are utilitarian supply functions: some plants can provide multiple products of value to humans, including medicinal, gardening, and economic benefits. The combination of different traits influences the interactions between plant community and ecological functions $[35,36]$. Green roof ecosystems with diverse plant functional traits can enhance ecological services [37-40].

Understanding the characteristics of plant functional traits facilitates the explanation and analysis of ecological functions $[7,41,42]$ and provides a reference for the planning and design of roof greening. The choice of species in roof greening should depend on commercial availability, aesthetic value, environmental adaptability, and root-depth standards [43]. However, the choice and types of species that are more able to enhance ecological functions can be beset by various problems. Beijing was one of the first cities in China to develop roof greening. In the course of implementation, ecological functions implied from the functional traits of roof-greening plants were considered. With rapid urbanization and population growth, Beijing is facing various urban problems such as air pollution, heat islands, congested urban spaces, etc. In terms of per unit and per capita provision, ground-level green spaces are not sufficient to alleviate environmental problems and enhance the quality of urban life. On the other hand, the roof greening area of Beijing only occupies about $1 \%$ of the total roof area. The current research on roof greening mainly focuses on plant screening [44], stress analysis, roof drainage [45], roof load and substrate selection [46], green infrastructure, and the spatial distribution pattern of roof greening and the corresponding factors [47]. Other studies on roof greening in Beijing tackle the choice of plants and their resistance to stress [48], the greening management mode [49], policy 
formulation, and development, construction, and maintenance methods [50]. Thus, Beijing has great potential for developing roof greening to improve its ecological environment. On a more practical level, whether the current roof greening plants provide adequate support for ecological services has not been adequately investigated. Furthermore, few studies touch on the assessment of all the four sets of ecological functions in the context of the relatively comprehensive ecosystem services that could be provided by roof-greening plants.

Based on field investigations, classification systems of plant functional traits [24-27], the Millennium Ecosystem Assessment (MA) ecosystem service function classification [8], and other related studies [40], this study probes plant functional traits and evaluates the ecological functions of roof greening plants in Beijing. From the findings, useful recommendations found for plant selection and ecological-function enhancement are provided to improve the planning and design of roof greening and maintain sustainable urban development, especially in rapidly urbanized areas.

\section{Materials and Methods}

\subsection{Study Area}

Beijing is located at $39^{\circ} 23^{\prime} \mathrm{N}-40^{\circ} \mathrm{N}, 115^{\circ} 20^{\prime} \mathrm{E}-117^{\circ} 30^{\prime} \mathrm{E}$ with an area of $16,410.54 \mathrm{~km}^{2}$ and a population of 21.73 million [51]. It has a continental monsoon climate with a cold and dry winter and a mild and moist summer. The annual mean precipitation is $682.9 \mathrm{~mm}$ and the frost-free period lasts 150-180 days [52]. The species diversity in urban greening is high. The plants are dominated by species of the tropical region, the northeastern cold zone, and Siberian flora [53]. At the end of 2017, the per capita public green space in Beijing was $16.2 \mathrm{~m}^{2}$ [51]. The total roof area was about 200 million $\mathrm{m}^{2}$, and the roof greening area reached more than 2 million $\mathrm{m}^{2}$ [54]. Roof greening has been verified to improve the microclimate of roofs in Beijing by decreasing the mean temperature by $2-3^{\circ}$, decreasing the wind velocity from $0.32-2.70 \mathrm{~m} / \mathrm{s}$ to $0.40-1.11 \mathrm{~m} / \mathrm{s}$ and increasing the relative humidity by $2.7 \%$ [55].

\subsection{Digital Data Collection and Field Studies}

Since most roof greening is distributed within the Fifth Ring Road of Beijing, only this region was considered for digital data collection and field studies. The region contains six districts with an uneven distribution of roof greening (2015) [56]: Chaoyang $\left(301,419 \mathrm{~m}^{2}\right.$, occupied $24.5 \%$ of the total) $>$ Dongcheng $\left(300,767 \mathrm{~m}^{2}, 24.4 \%\right)>$ Haidian $\left(254,965 \mathrm{~m}^{2}, 20.7 \%\right)>$ Xicheng $\left(228,756 \mathrm{~m}^{2}, 18.6 \%\right)>$ Fengtai $\left(113,788 \mathrm{~m}^{2}, 9.2 \%\right)>$ Shijingshan $\left(31,565 \mathrm{~m}^{2}, 2.6 \%\right)$.

We collected our species information by following four steps. First, we used digital maps to locate the positions of roof greening. Second, we carried out field studies to collect data on species planted on roofs. Third, we searched the literature to assemble more data on plant species grown on green roofs in Beijing. Fourth, we built a database to analyze the data.

The Getscreen auto-screen mosaic tool was first used to capture a Google Earth satellite image and retrieve the Geotiff format image in 2014. Then the grid image in Geotiff format was loaded into ArcGIS for digitization, and the spatial distribution map of roof greening within the Beijing Fifth Ring Road was obtained. From 201 objects, 51 plots were successfully reached and surveyed in field trips in August 2014. We investigated the characteristics of plant composition and the functional traits of each plant. We investigated the following aspects: (1) Characteristics of the surroundings, such as land use type, geographical location, and location layer in the building; (2) Characteristics of the roof greening, including types of roof greening, soil depth, and green ratios on the roofs; and (3) Plant information, including species name, number, height, etc.

\subsection{Classification of Plant Functional Traits and Ecological Functions}

Based on field investigations and assisted by the Global Plant Functional Attribute Classification System Handbook [26], Flora of Beijing [57,58], we summarized a list of plant functional traits (Table 1) by sorting the floristic composition of 207 plant species used for roof greening in Beijing. The key 
functional traits were selected to represent different organs of the plants, display the differences of ecological functions among plants and facilitate their evaluation. The parameters of the selected traits and their relationships with different ecological functions were set up (Table 2). A weight was assigned to each functional trait based on the number of its ecological functions (regulating, cultural, supporting, and supplying) (Table 3). The ecological function value of each plant was calculated by the following formula:

$$
\mathrm{EF}=\sum_{i=1}^{16}\left(P_{i} \times W_{i}\right)
$$

where EF is the ecological function value of each plant; $i$ is the functional trait; $P$ are the parameters of each plant's functional traits; and $W$ is the weight assigned to each functional trait.

Table 1. Plant functional traits.

\begin{tabular}{|c|c|c|}
\hline Functional Traits & Classification (Number of Species) & Note \\
\hline Growth form [59] & $\begin{array}{l}\text { 1. Herb (119); 2. Liana (11); 3. Semi-shrub (3); } 4 . \\
\text { Shrub (40); 5. Arbor (34) }\end{array}$ & \\
\hline Life form $[22,59]$ & $\begin{array}{c}\text { 1. Phanerophyte (76); } 2 \text {. Chamaephyte (14); } 3 . \\
\text { Hemicryptophyte (39); } 4 \text {. Geophyte (17); } 5 . \\
\text { Therophyte (61) }\end{array}$ & \\
\hline Growth habit [40] & $\begin{array}{l}\text { 1. Strong adaptability (187); } 2 \text {. Light preferring (99); } \\
\text { 3. Warm preferring }(69) ; 4 \text {. Humid preference }(68) ; 5 . \\
\text { Cold preference }(6) ; 6 . \text { Wind resistance }(77) ; 7 . \\
\text { Drought tolerance }(70) ; 8 \text {. Cold tolerance }(100) ; 9 . \\
\text { Heat tolerance; } 10 . \text { Shade tolerance; } 11 \text {. Salt tolerance; } \\
\text { 12. Barren tolerance; } 13 \text {. Waterlogging tolerance }\end{array}$ & The ecological amplitude of plants. \\
\hline Life cycle [60-62] & $\begin{array}{l}\text { 1. One year (61); } 2 . \text { Two years }(2) ; 3 . \text { More than two } \\
\text { years }(144)\end{array}$ & Life span of plants \\
\hline Plant architecture [63] & $\begin{array}{l}\text { 1. Basal leaves (33); Cauline leaves (191); 3. Multiple } \\
\text { stems (25); 4. Branching (144) }\end{array}$ & $\begin{array}{c}\text { Relationship between stem and } \\
\text { leaf }\end{array}$ \\
\hline Growth rate [40] & $\begin{array}{l}\text { 1. Fast (1-6 months) (95); } 2 \text {. Medium (7-12 months) } \\
(106) ; 3 \text {. Slow (13 months or more) }(6)\end{array}$ & $\begin{array}{l}\text { The duration from germinating, } \\
\text { flowering to ripe stages of fruit. }\end{array}$ \\
\hline The supplying value [63] & $\begin{array}{l}\text { 1. Medicinal (158); 2. Edible (47); } 3 \text { Fodder (30); } 4 . \\
\text { Gardening (108); 5. Economic (54); 6. Nutrition (17); } \\
\text { 7. None (4) }\end{array}$ & $\begin{array}{l}\text { Values that can be used directly by } \\
\text { humans }\end{array}$ \\
\hline Height [63] & $\begin{array}{l}\text { 1. Extremely tall }(301 \mathrm{~cm})(13) ; 2 \text {. Tall }(151-300 \mathrm{~cm}) \\
(37) ; 3 . \text { Medium tall }(101-150 \mathrm{~cm})(28) ; 4 . \text { Medium } \\
(51-100 \mathrm{~cm})(42) ; 5 \text {. Medium shorter }(31-50 \mathrm{~cm})(32) ; \\
6 \text { Short }(0-30 \mathrm{~cm})(55)\end{array}$ & The average height of plants \\
\hline Woody tissue [63] & 1. Wood-free 115); 2. Semi-woody (11); 3. Woody (81) & \\
\hline Stem growth pattern [63] & $\begin{array}{c}\text { 1. Erect stem (162) 2. Twining stem (6); 3. Climbing } \\
\text { stem (13); 4. Creeping stem (20); } 5 \text {. Prostrate stem (4); } \\
\text { 6. No ground stems (2) }\end{array}$ & Orientation of the stems \\
\hline Leaf phenology [64] & $\begin{array}{l}\text { 1. Evergreen (29); } 2 \text {. Shedding in summer (4); } 3 . \\
\text { Shedding in Autumn (122); } 4 \text {. Shedding in winter } \\
\text { (51); 5. Leafless (1) }\end{array}$ & \\
\hline Leaf blade size $[61,65]$ & $\begin{array}{l}\text { 1. Big leaf (longer }>20 \mathrm{~cm} \text { long and }>10 \mathrm{~cm} \text { wide) } \\
\text { (14); } 2 \text {. Medium leaf }(10-20 \mathrm{~cm} \text { long and }>5 \mathrm{~cm} \text { wide) } \\
\text { (55); } 3 \text {. Small leaf }(<10 \mathrm{~cm} \text { long and }<10 \mathrm{~cm} \text { wide) } \\
\text { (94); } 4 . \text { Coniferous needle or scale }(13) ; 5 . \text { Linear leaf } \\
(>10 \mathrm{~cm} \text { long and }<5 \mathrm{~cm} \text { wide) }(30) ; 6 . \text { Leafless }(1)\end{array}$ & \\
\hline Leaf color $[61]$ & $\begin{array}{l}\text { 1. Green (199); 2. Gray green (4); 3. Purple (4); } 4 . \\
\text { Yellow (2); 5. Multicolor (2); 6. Leafless (1) }\end{array}$ & \\
\hline Leaf texture [63] & $\begin{array}{l}\text { 1. Papery (111); 2. Fleshy (9); 3. Leathery (51); } 4 \text {. } \\
\text { Herbaceous (32); 5. Membranous (3); 6. Leafless (1) }\end{array}$ & \\
\hline Fleshy leafs [63] & 1. No (197); 2. Yes (10) & The ability to store water in leaves \\
\hline Flower color $[61]$ & $\begin{array}{c}\text { 1. White (33); 2. Red (29); 3. Yellow (62); 4. Blue (7); } 5 . \\
\text { Green (14); 6. Purple (25); 7. Multicolor (20); 8. No } \\
\text { flower }\end{array}$ & $\begin{array}{l}\text { Some plants have spikes but no } \\
\text { flower }\end{array}$ \\
\hline
\end{tabular}


Table 1. Cont.

\begin{tabular}{|c|c|c|}
\hline Functional Traits & Classification (Number of Species) & Note \\
\hline Flowing period $[61,64]$ & $\begin{array}{l}\text { 1. Spring (February-April) (19); 2. Spring-Summer } \\
\text { (March-June) (34); 3. Summer (May-July) (64); } 4 \text {. } \\
\text { Summer-Autumn (June-September) (62); 5. Autumn } \\
\text { (August- October) (14); } 6 \text { Winter } \\
\text { (November-January) (2); } 7.5 \text { months and above (12) }\end{array}$ & $\begin{array}{l}\text { For plants with spikes but no } \\
\text { flower, it refers to the spike period }\end{array}$ \\
\hline Fruiting period [61] & $\begin{array}{l}\text { 1. Spring-Summer (March-June) (11); } 2 \text {. Summer } \\
\quad \text { (May-July) (21); 3. Summer-Autumn } \\
\text { (June-September) (55); 4. Autumn (August-October) } \\
\text { (99); 5. Autumn-Winter (September-December) (7); } 6 \text {. } \\
\text { Winter (November-January) (2); } 7 . \geq 5 \text { months (7); } 8 \text {. } \\
\text { No fruit }\end{array}$ & \\
\hline Rooting depth [40] & 1. Shallow root (188); 2. Deep root (19) & \\
\hline Food Storage [61] & $\begin{array}{l}\text { 1. Fleshy root (7); } 2 \text {. Blocky root (4); } 3 \text {. Rhizomes (36); } \\
\text { 4. Tubers (2); } 7 \text {. None }(160)\end{array}$ & Place of the organ for food storage \\
\hline Main pollination Mode [61] & $\begin{array}{l}\text { 1. Wind media (49); } 2 . \text { Insect media (141); } 3 . \\
\text { Wind/insect media (16); } 4 \text {. Self-pollination (1) }\end{array}$ & \\
\hline Pollination feedback [61] & 1. Nectar (3); 2. Pollen (73); 3. Nectar and pollen (131) & \\
\hline Propagation mode [61] & $\begin{array}{l}\text { 1. Seed (170); 2. Rhizome (15); 3. Cutting (83); } 4 . \\
\text { Plant division (56); 5. Layering (37); 6. Grafting (35) }\end{array}$ & \\
\hline
\end{tabular}

Table 2. Ordinal coding for selected plant functional traits.

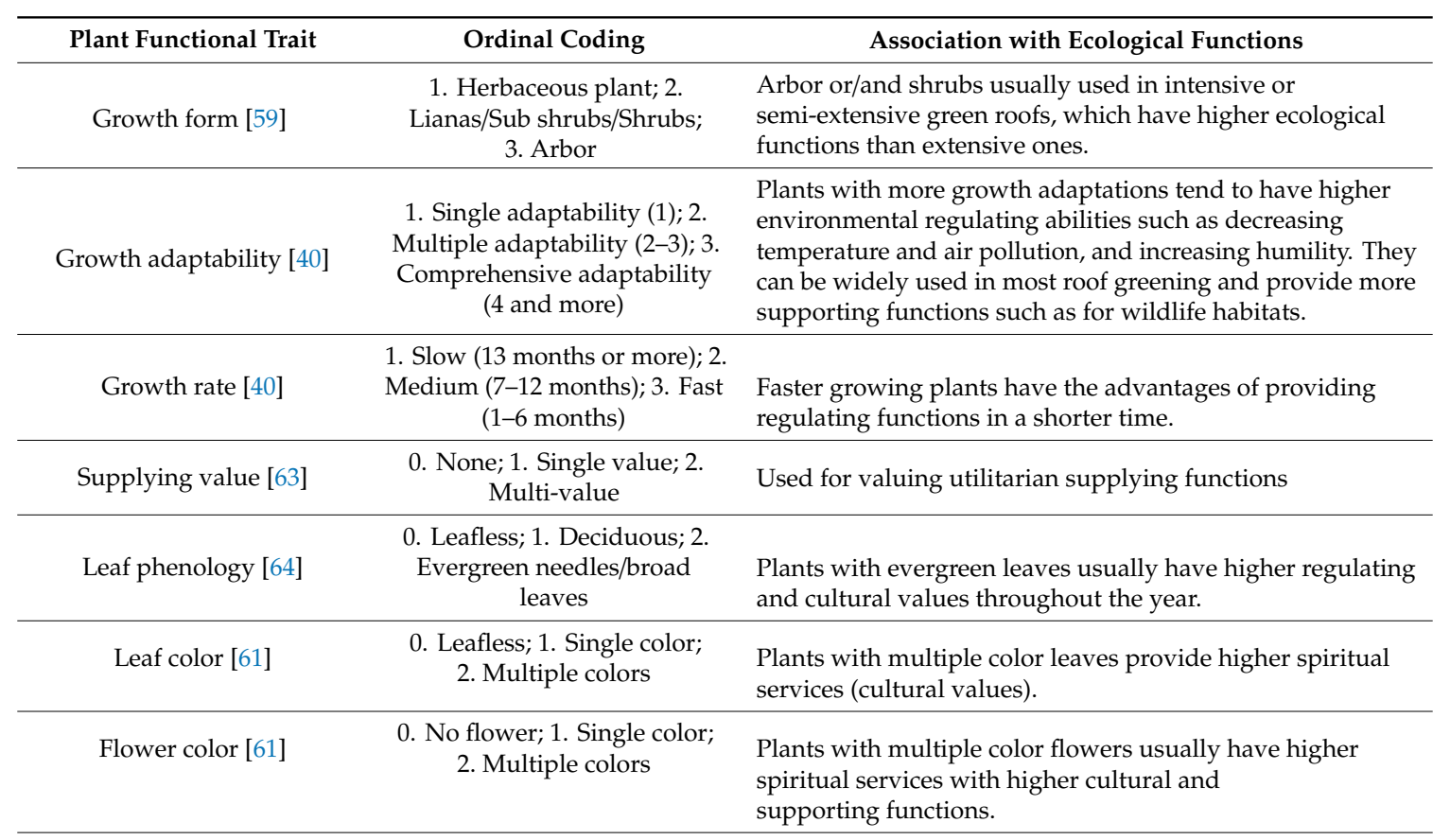

0 . No flower; 1 . Short

florescence (0-2 months); 2 .

Florescence $[61,64] \quad$ Medium florescence (2-4 months); 3 . Long florescence (5 months and longer)

Plants with longer flowering period can fulfill cultural and supporting values in an extended duration.

0 . No fruit; 1 . Short fruit period (0-2 months); 2 . Fruit period [61] Medium fruit period (2-4 months); 3. Long fruit period

(5 months and longer)

Fruits can serve ornamental function and food for wildlife. Plants with longer fruiting period can offer more cultural and supporting values.

Depth of the root [40] 1. Shallow roots; 2. Deep roots Plants with deep roots can survive better in dry weather and soil with limited moisture-holding capacity. 
Table 3. Weight of ecological functions assigned to each selected plant functional trait.

\begin{tabular}{cccccc}
\hline Plant Functional Trait & Regulating & Cultural & Supporting & Supplying & Weight \\
\hline Growth form & $\sqrt{ }$ & $\sqrt{ }$ & $\sqrt{ }$ & 3 \\
Growth adaptability & $\sqrt{ }$ & & $\sqrt{ }$ & 2 \\
Growth rate & $\sqrt{ }$ & & & $\sqrt{ }$ & 1 \\
The supplying value & & $\sqrt{ }$ & $\sqrt{ }$ & 3 \\
Leaf phenology & $\sqrt{ }$ & $\sqrt{ }$ & $\sqrt{ }$ & 1 \\
Leaf color & & $\sqrt{ }$ & $\sqrt{ }$ & 2 \\
Flower color & & $\sqrt{ }$ & $\sqrt{ }$ & 2 \\
Flowering period & & $\sqrt{ }$ & & 1 \\
Fruiting period & & & & \\
Rooting depth & $\sqrt{ }$ & & &
\end{tabular}

\section{Results}

\subsection{Distribution of Roof Greening in Beijing}

All 201 roof greening sites and the surveyed 51 plots are displayed in Figure 1. The site number and per cent of roof greening in each district are listed in Table 4. It can be inferred from Figure 1 and Table 4 that most existing roof greening and surveyed plots are concentrated in four districts: Haidian, Chaoyang, Dongcheng, and Xicheng, which are more densely populated and have more intense urbanization than other districts. Xicheng and Chaoyang contribute over half of the total number and area of roof greening sites.

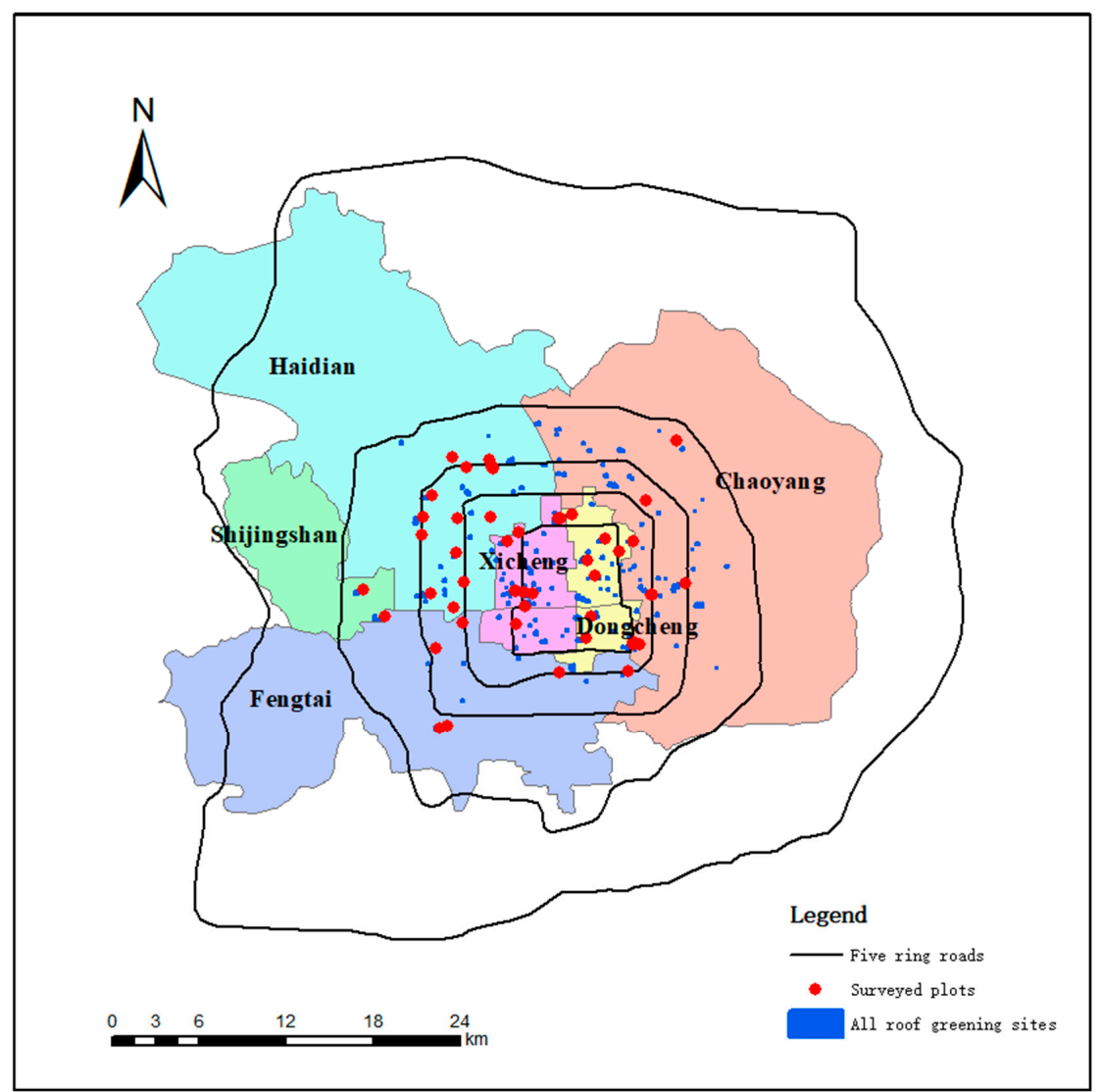

Figure 1. Geographical locations of all roof greening sites and surveyed plots within the six districts largely enveloped by the Beijing Fifth Ring Road. 
Table 4. Distribution of surveyed plots and all green roof sites within the Beijing Fifth Ring Road.

\begin{tabular}{|c|c|c|c|c|c|c|c|c|}
\hline \multicolumn{2}{|c|}{ District * } & Haidian & Chaoyang & Dongcheng & Xicheng & Fengtai & Shijingshan & Total \\
\hline \multirow{2}{*}{\multicolumn{2}{|c|}{$\begin{array}{l}\text { Site (number) } \\
\text { Site (per cent) }\end{array}$}} & 39 & 50 & 39 & 54 & 15 & 4 & 201 \\
\hline & & 19.40 & 24.88 & 19.40 & 26.87 & 7.46 & 2.00 & 100 \\
\hline \multirow{4}{*}{$\begin{array}{l}\text { Site area } \\
\left(\left(\mathrm{m}^{2}\right)\right.\end{array}$} & Maximum & 6716 & 9693 & 60,183 & 6331 & 2414 & 3717 & 60,183 \\
\hline & Minimum & 111 & 156 & 62 & 26 & 59 & 439 & 26 \\
\hline & Mean & 1698.44 & 2280.88 & 3380.46 & 1636.76 & 730.73 & 1994 & 2086.78 \\
\hline & Total & 66,239 & 114,044 & 131,838 & 88,385 & 10,961 & 7976 & 419,443 \\
\hline \multicolumn{2}{|c|}{ Plot (number) } & 16 & 9 & 7 & 11 & 7 & 1 & 51 \\
\hline \multicolumn{2}{|c|}{ Plot (per cent) } & 31.37 & 17.65 & 13.73 & 21.57 & 13.73 & 1.96 & 100 \\
\hline \multirow{4}{*}{$\begin{array}{l}\text { Plot area } \\
\qquad\left(\mathrm{m}^{2}\right)\end{array}$} & Maximum & 6716 & 9652 & 7741 & 5713 & 1020 & 1221 & 9652 \\
\hline & Minimum & 111 & 273 & 62 & 26 & 59 & 1221 & 26 \\
\hline & Mean & 1708.13 & 2592.67 & 2717.71 & 1134.73 & 514 & 1221 & 1705.67 \\
\hline & Total & 27,330 & 23,334 & 19,024 & 12,482 & 3598 & 1221 & 86,989 \\
\hline
\end{tabular}

* Sites are all the green roofs in six districts; plots are the sites surveyed during the field trips.

The surveyed plots of roof greening were classified into extensive roof greening, extensive platform greening, intensive roof greening, and intensive platform greening. The number of greening types in the field investigation and their ratios are shown in Table 5. It can be inferred from Table 5 that greening on roofs and extensive greening occupied more than $75 \%$ of the total plots. The plots were usually located in hospitals, schools, commercial districts, residential areas, government offices, etc. Among these, the commercial area has a higher availability of roof greening with plants that are more recreational and ornamental in nature. Most government office areas have extensive roof greening with low accessibility. In hospitals, both extensive and intensive roof greening exist. Intensive roof greening provides patients and their families with leisure and entertainment services, whereas extensive roof greening is almost impossible to reach in most cases. In residential areas, most public greening is on a platform within the community. The public platform greening always plants on a high platform for amusement or for parking, as seen in the intensive platform greening of Wangjing Garden and Jianwai $\mathrm{SOHO}$ (small office, home office). Private roof greening in residential areas has not been included in this field investigation. From long-distance visual observation its plant composition is rich and beautiful with high entertainment value, but it only serves the residential area owners.

Table 5. Roof greening types of surveyed plots.

\begin{tabular}{|c|c|c|c|c|c|}
\hline Greening Type & $\begin{array}{l}\text { Extensive Roof } \\
\text { Greening }\end{array}$ & $\begin{array}{l}\text { Extensive Platform } \\
\text { Greening }\end{array}$ & $\begin{array}{l}\text { Intensive Roof } \\
\text { Greening }\end{array}$ & $\begin{array}{l}\text { Intensive Platform } \\
\text { Greening }\end{array}$ & Total \\
\hline Plot number & 26 & 6 & 15 & 4 & 51 \\
\hline Ratio & $50.98 \%$ & $11.76 \%$ & $29.41 \%$ & $7.84 \%$ & $100 \%$ \\
\hline Greening type & \multicolumn{2}{|c|}{ Extensive greening } & & Intensive greening & \\
\hline Plot number & \multicolumn{2}{|c|}{32} & & 19 & 51 \\
\hline Ratio & \multicolumn{2}{|c|}{$62.75 \%$} & & $37.25 \%$ & $100 \%$ \\
\hline Greening type & \multicolumn{2}{|c|}{ Roof greening } & & Platform greening & \\
\hline Plot number & \multirow{2}{*}{\multicolumn{2}{|c|}{$\begin{array}{c}41 \\
80.39 \%\end{array}$}} & & 10 & 51 \\
\hline Ratio & & & & $19.61 \%$ & $100 \%$ \\
\hline
\end{tabular}

\subsection{Taxonomic Characteristics of Roof Greening Plants}

According to the field investigation and related literature [48], 207 plants used in Beijing roof greening are summarized (see Supplementary Materials). They belong to 161 genera from 61 families (Supplementary Materials). It can be inferred from the Supplementary Materials that Compositae has 31 species from 24 genera, occupying 15\%; Rosaceae has 21 species from 12 genera, occupying 10\%; Gramineae has 13 species from 13 genera, occupying 6\%; and Cupressaceae has nine species from five genera, occupying 4\%. Crassulaceae sp., Cucurbitaceae sp., Leguminosae sp., Oleaceae sp., Chenopodiaceae sp., Lamiaceae Martinov sp. and Convolvulaceae sp. occupy 3\% of the plants. Each of the other families account for less than $3 \%$ of the plants. 


\subsection{Functional Traits of Roof Greening Plants}

According to the characteristics of plant functional traits listed in Table 2, a large number of roof greening plants in Beijing are phanerophytes (76 species, $58 \%$ of the total, dominated by Cupressaceae sp. and Rosaceae sp.) and therophytes (61 species, $29 \%$ of the total, dominated by Compositae sp., Cucurbitaceae sp. and Gramineae sp.). Most are herbaceous plants (119 species, 58\% of the total, dominated by Compositae sp. and Gramineae sp.), perennial species (144 species, 70\% of the total, dominated by Rosaceae sp., Compositae sp., and Cupressaceae sp.), and those with a faster growing rate (201 species, 97\% of the total). They often have cauline leaves and multiple stems and branches, such as Ixeridium sonchifolium (Maxim.) Shih of Compositae and Buddleja davidii Franch. of Loganiaceae. Most plants have strong adaptation and are tolerant to the cold, heat, drought, and wind. They usually also have multiple supplying values, especially medicinal, gardening, and economic value, such with Sedum lineare Thunb. of Crassulaceae, Ixeridium chinense (Thunb.) Nakai of Compositae, and Agrimonia pilosa Ldb. of Rosaceae.

The plant heights are dwarf ( 55 species, $26 \%$ of the total, dominated Compositae sp. and Crassulaceae sp.), medium ( 42 species, $20 \%$ of the total, dominated by Compositae sp.), and high ( 37 species, $18 \%$ of the total, dominated by Rosaceae sp. and Oleaceae sp.). Most plants have erect stems (162 species, 78\% of the total), and no woody characteristics (115 species, $56 \%$ of the total, dominated by Compositae sp., Gramineae sp., and Cucurbitaceae sp.).

Most plants are deciduous (178 species, $86 \%$ of the total), and the senescence period is mainly in autumn (122 species, 59 of the total). Most leaves of the plants are small (94 species, $45 \%$ of the total). The texture of the leaf is mostly papery (111 species, $54 \%$ of the total) and not fleshy ( 197 species, $95 \%$ of the total). The leaf color is mostly green (194 species, $94 \%$ of the total).

The flower color of $30 \%$ of plants is yellow (62 species). The anthesis of most plants is in the summer (64 species, 31\% of the total) or the summer-autumn transition season (62 species, $30 \%$ of the total). There are 12 species where the anthesis lasts 5 months or longer. The fruit period is always in autumn (99 species, $48 \%$ of the total) and approximately seven species have a fruit period of more than 5 months.

Most plants have shallow roots (188 species, $91 \%$ of the total, dominated by Compositae sp., Rosaceae sp., and Gramineae sp.), and have no underground organ to store nutrients (160 species, 77\% of the total, dominated by Rosaceae sp., Compositae sp., and Gramineae sp.). A few plants have fleshy roots (Sedum sarmentosum Bunge of Crassulaceae), root tubers (Cirsium japonicum Fisch. ex DC. of Compositae), and rhizomes or tubers.

The propagating methods of the plants are diverse. Most plants have more than one propagation method. They usually select entomophily (141 species, $68 \%$ of the total, such as Compositae sp., Rosaceae sp., and Crassulaceae sp.) as the main method, because most of such plants have nectar and pollen (131 species, $63 \%$ of the total).

\subsection{Ecological Functions by Roof Greening Plants}

The relative values of ecological functions calculated by the different functional traits of the plants are listed in Supplementary Material Table S1. Based on this, a comparison chart of four ecological functions is obtained (Figure 2). 


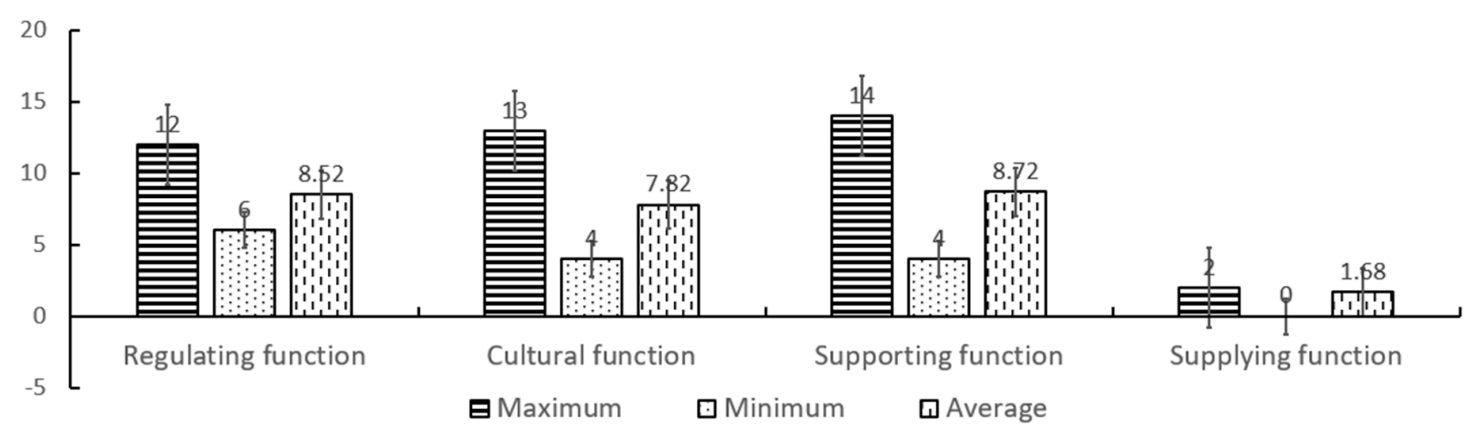

Figure 2. Value comparison with standard error of regulating, cultural, supporting, and supplying functions of roof greening plants.

The regulating function values of the plants range from 6 to 12 , with a mean of 8.52. Phyllostachys propinqua McClure of Gramineae, Rosa chinensis Jacq. of Rosaceae, Ligustrum japonicum Thunb. of Oleaceae, and Ulmus macrocarpa Hance of Ulmaceae have the highest value of 12. About nine species including Artemisia annua Linn., Artemisia selengensis Turcz. ex Bess., and Heteropappus altaicus (Willd.) Novopokr. of Composita have the lowest value of 6 . Overall, 88 species have a value higher than the mean. Rosaceae sp. are the most frequent, with 15 species including Malus spectabilis (Ait.) Borkh., Prunus Cerasifera Ehrhar f. atropurpurea (Jacq.) Rehd., and Cotoneaster horizontalis Dcne. About 118 species have values below the average, and Compositae sp. are the most frequent, with 27 species including Taraxacum mongolicum Hand.-Mazz., Saussurea japonica (Thunb.) DC., and Bidens pilosa L. var. radiate Sch. Bip.

The cultural function values of the plants range from 4 to 13, with a mean of 7.82. Ligustrum japonicum Thunb. of Oleaceae and Hedera nepalensis var. sinensis (Tobl.) Rehd of Araliaceae have the highest value of 13. Triarrhena sacchariflora (Maxim.) Nakai of Gramineae, Amaranthus lividus L. of Amaranthaceae, and Cuscuta chinensis Lam. of Convolvulaceae have the lowest value of 4 . A total of 68 species have higher than average culture function values, and Compositae sp. are the most frequent, with 25 species including Taraxacum mongolicum Hand.-Mazz. and Cirsium japonicum Fisch. ex DC. There are 138 species which have values below the average, and Gramineae sp. are the most frequent, with 12 species including Eragrostis pilosa (L.) Beauv. and Poa pratensis L.

The supporting function values of the plants range from 4 to 14 , with a mean of 8.72. Ligustrum japonicum Thunb. of Oleaceae has the highest value of 14. Amaranthus lividus L. of Amaranthaceae has the lowest value of 4 . In total, 123 species have higher than average values, and Rosaceae sp. are the most frequent, with 17 species including Rosa chinensis Jacq., Amygdalus persica L., and Cerasus yedoensis (Matsum.) Yu et Li. Overall, 83 species have values below the average, and Compositae sp. are the most frequent, with 15 species including Saussurea japonica (Thunb.) DC., Ixeris sonchifolia Hance, and Tagetes erecta L.

There are 144 species that have multi-use supplying functions, and Compositae sp. are the most frequent, with 21 species including Sonchus oleraceus L., Ixeridium chinense (Thunb.) Nakai, and Lagedium sibiricum (L.) Sojak. There are 59 species that have a single use, and Compositae sp. and Rosaceae sp. both occupy the majority, with nine species including Bidens pilosa L., Cirsium japonicum, and Gerbera anandria (L.) Sch.-Bip. of Compositae and Spiraea japonica L. f., Potentilla tanacetifolia Willd. ex Schlecht., Potentilla supine L. of Rosaceae. There are three species with no use: Heteropappus altaicus (Willd.) Novopokr. of Compositae, Cyperus nipponicus Franch. et Savat of Cyperaceae, and Axyris amaranthoides L. of Chenopodiaceae.

The total values of plant ecological functions range from 18 to 41 with two species above 35, Calystegia hederacea Wall.ex.Roxb. of Convolvulaceae and Ulmus macrocarpa Hance of Ulmaceae. Four species have comparatively low total ecological function values of less than 20, including Amaranthus lividus L. of Amaranthaceae, Saluia plebeia R. Br. of Labiatae, Gueldenstaedtia stenophylla Bunge of Leguminosae, and Carex heterostachya Bge. of Cyperaceae. 


\subsection{Plant Ecological Functions in Different Families}

Table 6 shows the mean values of plant ecological functions in different families. It can be inferred from Table 6 that about eight families have the highest mean regulating function values as compared to other families, at $\geq 11$. These are Buxaceae (11), Ulmaceae (12), Rhamnaceae (11), Aceraceae (11), Moraceae (11), Buxaceae (11), Celastraceae (11), Sapindaceae (11), and Ginkgoaceae (11). Solanaceae, Apiaceae, Oxalidaceae, Calycanthaceae, Labiatae, Liliaceae, and Amaranthaceae have the lowest mean regulating function value of 7. Araliaceae and Nyctaginaceae have the highest mean cultural function values of 13 and 11, respectively. In addition, Gramineae and Amaranthaceae have the lowest mean cultural function value of 5 . Eight families have the highest mean supporting function values at $\geq 11$. They are Nyctaginaceae (15), Loganiaceae (13), Araliaceae (12), Lythraceae (11), Bignoniaceae (11), Ulmaceae (11), Berberidaceae (11), and Verbenaceae (11). Gramineae (6), Apiaceae (6), and Amaranthaceae (5) have the lowest mean supporting function values at $\leq 6$. Overall, 51 families have a mean supplying function value of 2 , and 10 families have a mean supplying function of 1 . There are 39 families that have a higher total function value than the mean value of 26.9 , of which Ulmaceae has the highest value of 37 , followed by Sapindaceae and $e$ with a value of 35 , and Berberidaceae and Aceraceae with a value of 34 . Labiatae has the lowest total function value of 20, followed by Amaranthaceae and Saxifragaceae with a value of 21 .

Table 6. The mean values of plant ecological functions in different families.

\begin{tabular}{|c|c|c|c|c|c|}
\hline & $\begin{array}{l}\text { Mean Regulating } \\
\text { Function Value }\end{array}$ & $\begin{array}{l}\text { Mean Cultural } \\
\text { Function Value }\end{array}$ & $\begin{array}{l}\text { Mean Supporting } \\
\text { Function Value }\end{array}$ & $\begin{array}{l}\text { Mean Supplying } \\
\text { Function Value }\end{array}$ & $\begin{array}{l}\text { Overall Mean } \\
\text { Value }\end{array}$ \\
\hline Ulmaceae & 12 & 9 & 11 & 2 & 37 \\
\hline Sapindaceae & 11 & 8 & 9 & 2 & 35 \\
\hline Ginkgoaceae & 11 & 8 & 9 & 2 & 35 \\
\hline Aceraceae & 11 & 8 & 9 & 2 & 34 \\
\hline Berberidaceae & 10 & 9 & 11 & 2 & 34 \\
\hline Verbenaceae & 10 & 9 & 11 & 2 & 33 \\
\hline Cannaceae & 8 & 8 & 9 & 2 & 33 \\
\hline Rubiaceae & 8 & 9 & 9 & 2 & 32 \\
\hline Betulaceae & 10 & 8 & 9 & 2 & 32 \\
\hline Buxaceae & 11 & 9 & 10 & 2 & 31 \\
\hline Celastraceae & 11 & 9 & 10 & 2 & 31 \\
\hline Scrophulariaceae & 8 & 9 & 10 & 2 & 31 \\
\hline Araliaceae & 8 & 13 & 13 & 2 & 31 \\
\hline Bignoniaceae & 10 & 9 & 11 & 2 & 31 \\
\hline Asclepiadaceae & 9 & 9 & 10 & 2 & 30 \\
\hline Pinaceae & 10 & 10 & 10 & 2 & 30 \\
\hline Simaroubaceae & 10 & 8 & 8 & 2 & 30 \\
\hline Meliaceae & 10 & 8 & 9 & 2 & 30 \\
\hline Lythraceae & 9 & 9 & 11 & 2 & 30 \\
\hline Magnoliaceae & 10 & 9 & 10 & 2 & 30 \\
\hline Rhamnaceae & 11 & 8 & 10 & 1 & 30 \\
\hline Convolvulaceae & 8 & 8 & 9 & 1 & 29 \\
\hline Oleaceae & 9 & 8 & 9 & 2 & 29 \\
\hline Cornaceae & 9 & 8 & 9 & 2 & 29 \\
\hline Caryophyllaceae & 8 & 9 & 10 & 1 & 29 \\
\hline Rosaceae & 9 & 8 & 9 & 2 & 28 \\
\hline Geraniaceae & 8 & 8 & 9 & 1 & 28 \\
\hline Loganiaceae & 9 & 10 & 12 & 2 & 28 \\
\hline Chenopodiaceae & 8 & 8 & 9 & 2 & 28 \\
\hline Moraceae & 11 & 8 & 10 & 2 & 28 \\
\hline Cupressaceae & 10 & 9 & 10 & 2 & 28 \\
\hline Violaceae & 8 & 9 & 10 & 2 & 28 \\
\hline Vitaceae & 10 & 8 & 9 & 2 & 28 \\
\hline Crassulaceae & 9 & 7 & 8 & 2 & 27 \\
\hline Iridaceae & 8 & 7 & 9 & 2 & 27 \\
\hline
\end{tabular}


Table 6. Cont.

\begin{tabular}{|c|c|c|c|c|c|}
\hline & $\begin{array}{l}\text { Mean Regulating } \\
\text { Function Value }\end{array}$ & $\begin{array}{l}\text { Mean Cultural } \\
\text { Function Value }\end{array}$ & $\begin{array}{l}\text { Mean Supporting } \\
\text { Function Value }\end{array}$ & $\begin{array}{l}\text { Mean Supplying } \\
\text { Function Value }\end{array}$ & $\begin{array}{c}\text { Overall Mean } \\
\text { Value }\end{array}$ \\
\hline Phytolaccaceae & 8 & 7 & 8 & 2 & 27 \\
\hline Malvaceae & 9 & 8 & 9 & 2 & 27 \\
\hline Calycanthaceae & 7 & 8 & 9 & 2 & 27 \\
\hline Caprifoliaceae & 9 & 8 & 10 & 2 & 27 \\
\hline Compositae & 8 & 8 & 9 & 2 & 26 \\
\hline Solanaceae & 7 & 9 & 10 & 2 & 26 \\
\hline Euphorbiaceae & 8 & 7 & 8 & 2 & 26 \\
\hline Nyctaginaceae & 10 & 11 & 15 & 2 & 26 \\
\hline Polygonaceae & 8 & 8 & 9 & 1 & 26 \\
\hline Ranunculaceae & 8 & 7 & 8 & 2 & 26 \\
\hline Punicaceae & 9 & 7 & 9 & 2 & 26 \\
\hline Plantaginaceae & 8 & 8 & 9 & 2 & 25 \\
\hline Oxalidaceae & 7 & 8 & 9 & 1 & 25 \\
\hline Cucurbitaceae & 8 & 7 & 8 & 2 & 25 \\
\hline Cruciferae & 8 & 8 & 8 & 2 & 25 \\
\hline Portulacaceae & 8 & 8 & 9 & 2 & 25 \\
\hline Commelinaceae & 8 & 8 & 9 & 1 & 25 \\
\hline Gramineae & 8 & 5 & 6 & 2 & 24 \\
\hline Cyperaceae & 8 & 8 & 9 & 1 & 24 \\
\hline Leguminosae & 8 & 7 & 8 & 2 & 24 \\
\hline Liliaceae & 7 & 8 & 8 & 2 & 24 \\
\hline Umbelliferae & 7 & 6 & 6 & 2 & 24 \\
\hline Ericaceae & 8 & 7 & 7 & 2 & 22 \\
\hline Amaranthaceae & 7 & 5 & 5 & 2 & 21 \\
\hline Saxifragaceae & 9 & 6 & 7 & 1 & 21 \\
\hline Lamiaceae & 7 & 7 & 8 & 1 & 20 \\
\hline
\end{tabular}

\section{Conclusions and Discussion}

By analyzing the functional traits of roof greening plants in Beijing, it was found that the four ecological functions differed significantly by plants. Firstly, Phyllostachys propinqua McClure of Gramineae, Rosa chinensis Jacq. of Rosaceae, Ligustrum japonicum Thunb. of Oleaceae, and Ulmus macrocarpa Hance of Ulmaceae have the highest regulating function value. Around nine species have the lowest values, including Artemisia annua Linn., Artemisia selengensis Turcz. ex Bess., and Heteropappus altaicus (Willd.) Novopokr. of Composita. Secondly, Ligustrum japonicum Thunb. of Oleaceae and Hedera nepalensis var. sinensis (Tobl.) Rehd of Araliaceae have the highest cultural function value, and Triarrhena sacchariflora (Maxim.) Nakai of Gramineae, Amaranthus lividus L. of Amaranthaceae, and Cuscuta chinensis Lam. of Convolvulaceae have the lowest value. Thirdly, Ligustrum japonicum Thunb. of Oleaceae has the highest supporting function value, and Amaranthus lividus L. of Amaranthaceae has the lowest. Fourthly, more than half of the plants have a wide range of supplying uses, whereas Heteropappus altaicus (Willd) Novopokr of Compositae, Cyperus nipponicus Franch. et Savat. of Cyperaceae, and Axyris amaranthoides of Chenopodiaceae have the lowest supplying function value. Fifthly, the overall mean ecological function values were obtained by summarizing the four ecological functions. Calystegia hederacea Wall.ex.Roxb. of Convolvulaceae and Ulmus macrocarpa Hance of Ulmaceae have the highest overall mean ecological function values. Amaranthus lividus L. of Amaranthaceae, Saluia plebeia R. Br. of Labiatae, Gueldenstaedtia stenophylla Bunge of Leguminosae, and Carex heterostachya Bge. of Cyperaceae have the lowest value. In addition, Rosaceae sp. have more species with higher levels of overall ecological function than the others, and Compositae sp. have more species with lower levels. Differences in the four ecological functions were also significant by families. Compared to other families, Araliaceae and Nyctaginaceae have a higher mean cultural and supporting function values. Ulmaceae has a highest mean overall function value of 37. Ulmaceae, Sapindaceae, Ginkgoaceae, Berberidaceae, and Aceraceae have higher mean regulating, cultural, supporting, and overall function values. Amaranthaceae, Umbelliferae, Lamiaceae, Saxifragaceae, Ericaceae, and Gramineae have lower mean regulating, cultural, supporting, and overall function values. 
The key aim of this paper was to reveal the ecological function values of Beijing roof greening plants by analyzing their functional traits. Inferred from the analyses, the following problems exist in Beijing's roof greening plants. Firstly, the composition structure of roof greening plants is unreasonable. Although 161 species of plants from 61 families are applied to roof greening, the number of plants from different families varies greatly. For example, the number of Compositae sp. accounts for $44 \%$ of the total, and about 50 families make up less than $3 \%$ of the total as a whole. This is also a common problem in the current roof greening in China. For example, the survey on roof greening in Pu'er City, Yunnan Province, showed that the local form of roof greening is singular and the ecological benefits are not maximized [66]. A survey on roof greening in Lanzhou, Gansu Province, showed that the local roof greening plants are not properly selected. The types are simple and seasonality is lacking [67]. Another survey found that Chongqing has abundant plant resources, but insufficient plant species are used in roof greening [68]. Secondly, the selection of plants does not consider the ecological functions. For example, many species of Compositae and Gramineae are used in roof greening, but their ecological function levels are low. The overall ecological function levels of Berberidaceae and Sapindaceae are high, but their species are deficient.

The future construction of roof greening in Beijing should focus on plants with high values in ecological function. The following are suggestions for improvement. Firstly, a possible course of action is increasing the numbers of plants that are strong at adaptation and have shallow roots, especially those tolerating wind, cold, drought, heat, and barren habitats, such as Sedum lineare Thunb., Sedum sarmentosum Bunge., Malus spectabilis (Ait.) Borkh., Amygdalus persica L. var. persica f. duplex Rehd., and Hedera nepalensis var. sinensis (Tobl.) Rehd. Most Crassulaceae sp. have good drought resistance through drought stress and other means [69]. Plants with deep roots such as Wisteria sinensis, Ulmus pumila L., and Morus alba L., are not suitable for planting on roofs. A second suggestion is enriching the ecological community and diversifying the species of herbaceous plants, shrubs, and lianas with high ecological functions. Sedum lineare Thunb. is the most widely used vegetation roofing material. However, due to long-term single planting and lack of cultivation, problems such as baldness, degeneration, and death are prominent. Among the species that belong to Crassulaceae sp., the drought-resistant perennial flowers are a large class of roof plants and should be studied deeply for future planting in roof greening [44]. More plants with rich colors and long florescence can be cultivated, such as Chaenomeles speciosa (Sweet) Nakai, Cerasus yedoensis (Matsum.) Yu et Li, and Rosa chinensis Jacq. Native plants with colorful leaves or evergreen native plants can be considered as well. For example, Berberis thunbergii var. atropurpurea Chenault has purple-red leaves, and Cedrun deodara and Ilex ficoidea Hemsl. var. parvifilia S. H. Fu var are evergreen. A third suggestion is carrying out rational ecological planning and management of roof greening to enhance ecological function levels [7]. Ecological planning includes the connection between the composition structure and distribution characteristics of plants and the regional ecosystem. Ecological management includes advanced ecological engineering technology, an appropriate management system, and the training of professional managers.

Screening suitable species is necessary for successful greening on roofs, where there are often extreme environmental conditions such as high illumination intensity, long illumination time, high-temperature differences between day and night, low air humidity, high wind speed, and a thin soil layer. This study indicated that the functional traits of roof plants are closely related to the roof environment. Usually, roof plants characterized by small leaves, short and shallow roots, fast growth rate, and diverse breeding methods are tolerant to cold, heat, drought, and wind. Thus, characterizing plant functional traits is an efficient way to predict their functions or services for various purposes in roof greening, without considering geographic distribution, ecological niche, and taxonomic/phylogenetic relationships [7]. Each type of ecological function has many detailed perspectives. One single plant functional trait may not be enough to reflect each ecological function. Thus, in order to get relatively accurate values of ecological functions, a set of related plant traits should be considered. 
This study is helpful in green roof establishment for several reasons. Firstly, it has theoretical meaning because it assesses all the four ecological functions such as regulating, supporting, cultural, and supplying functions using a relatively comprehensive set of functional traits of plants on roof greening, and evaluates the differences of each function by plants and families. Secondly, it has practical meaning because it provides conclusions on the problems occurring in Beijing roof greening and provides useful information about screening suitable species and enhancing ecological functions. Because of the large amount of data and high technical requirements, more studies should be performed in the future to specify plant functional traits and to evaluate more detailed ecological functions such as regulating temperature and humidity, alleviating air pollution, conserving water, enhancing aesthetic, entertainment, and spiritual functions, and providing nutrient circulation, as well as medicinal, gardening, and economic value.

Supplementary Materials: The following are available online at http://www.mdpi.com/2071-1050/11/19/5310/s1, Table S1: Plants of roof greening and their ecological functions in Beijing.

Author Contributions: Conceptualization, Y.T. and C.Y.J.; methodology and formal analysis F.Z.; investigation, Y.T. and F.Z.; writing_-original draft preparation, F.Z., T.W., and T.X.; writing—review and editing, Y.T. and J.J.; supervision, project administration and funding acquisition, Y.T.

Funding: This research was funded by Key Projects of National Natural Science Foundation of China (Project Nr. 41530747) and Project supported by State Key Laboratory of Earth Surface Processes and Resources Ecology (2017-FX-01(1)).

Conflicts of Interest: The authors declare no conflict of interest.

\section{References}

1. Ma, Y.P.; Dong, G.Y. Design and Construction of Roof Greening; China Machine Press: Beijing, China, 2010. (In Chinese)

2. FLL. Guidelines for the Planning, Construction and Maintenence of Green Roofing: Green Roof Guideline, 6th ed.; Forschungsgesellschaft Landschaftsentwicklung Landschaftsbau E. V.: Bonn, Germany, 2018.

3. Thuring, C.E.; Dunnett, N.P. Persistence, loss and gain: Characterising mature green roof vegetation by functional composition. Landsc. Urban Plan. 2019, 185, 228-236. [CrossRef]

4. Ouldboukhitine, S.E.; Belarbi, R.; Jaffal, I.; Trabelsi, A. Assessment of green roof thermal behavior: A coupled heat and mass transfer model. Build. Environ. 2011, 46, 2624-2631. [CrossRef]

5. Dunnett, N.; Nolan, A. The effect of substrate depth and supplementary watering on the growth of nine herbaceous perennials in semi-extensive green roof. Acta Hortic. 2004, 643, 305-309. [CrossRef]

6. Chen, C.D.; Bao, S.X. Urbanization in China and the trends of its development. Acta Ecol. Sin. 1994, 14, 84-89.

7. Lundholm, J.; Tran, S.; Gebert, L. Plant functional traits predict green roof ecosystem Services. Environ. Sci. Technol. 2015, 49, 2366-2374. [CrossRef]

8. Millennium Ecosystem Assessment (MA). Ecosystems and Human Well-Being: Synthesis; Island Press: Washington, DC, USA, 2005; 160p.

9. Carter, T.; Jackson, C.R. Vegetated roofs for stormwater management at multiple spatial scales. Landsc. Urban Plan. 2007, 80, 84-94. [CrossRef]

10. Cascone, S.; Gagliano, A.; Poli, T.; Sciuto, G. Thermal performance assessment of extensive green roofs invetigating realsitic vegettaion-substrate configuations. Build. Simul. 2019, 12, 379-393. [CrossRef]

11. Wang, L.M.; Qin, J.; Chen, B.S.; Hu, Y. Influence of roof garden on architecture microclimates. Chin. Agric. Sci. Bull. 2006, 22, 236-238.

12. Shafique, M.; Kim, R.; Rafiq, M. Green roof benefits, opportunities and challenges-A review. Renew. Sustain. Energy Rev. 2018, 90, 757-773. [CrossRef]

13. Lu, M.; Li, Y.J.; Lu, J.P. Absorption and Purification to Main Air Pollutants by Tree Species. Urban Environ. Urban Ecol. 2002, 2, 7-9.

14. Jia, Y.L.; Wang, D.Y. The ecological function of roof greening. Xiandai Hortic. 2011, 11, 140-141, (In Chinese with English Abstract).

15. Wang, H. Functional analysis of domestic forest system ecology significance and service. Forest Explor. Design 2015, 3, 27-29, (In Chinese with English Abstract). 
16. Wang, W.L. Study on Four Seasons Changes of Nosie Reduction Effect of Urban Green Belt in Beijing. Master's Thesis, Beijing Forestry University, Beijing, China, 2012. (In Chinese with English Abstract).

17. Wang, Z.H.; Duan, C.Q.; Hou, Y.P.; Yang, J. The relationship of plant species diversity to ecosystem function in relation to soil conservation in semi-humid evergreen forests, Yunnan province, China. J. Plant Ecol. 2006, 30, 392-403, (In Chinese with English Abstract).

18. Madre, F.; Vergnes, A.; Machon, N.; Clergeau, P. Green roofs as habitats for wild plant species in urban landscapes: First insights from a large-scale sampling. Landsc. Urban Plan. 2014, 122, 100-107. [CrossRef]

19. Luo, H.; Wang, N.; Zhao, Y.J.; Zhou, B. Species of invasive edible plants in China and their edibility assessment. Chin. J. Ecol. 1886, 34, 1886-1891, (In Chinese with English Abstract).

20. Meng, F. Comprehensive Environment Construction of the Landscape Value of Ornamental Prunus Mume and Application Advices in Nanjing Area. Master's Thesis, Nanjing Agriculture University, Nanjing, China, 2016. (In Chinese with English Abstract).

21. Lan, F.N.; Jiang, Z.C.; Xie, Y.Q.; Zhang, M. Studies on the nutrition value and feeding effect of several forage cultivars in karst mountainous region. Pratacult. Sci. 2008, 25, 84-87.

22. Raunkiaer, C.; Egerton, F.F.N.; Carter, H.G. The Life Forms of Plants and Statistical Plant Geography; The Clarendon press: Oxford, UK, 1934.

23. Grime, J.P. Vegetation classification by reference to strategies. Nature 1974, 250, 26-31. [CrossRef]

24. McIntyre, S.; Lavorel, S.; Landsberg, J.; Forbes, T.D.A. Disturbance response in vegetation-towards a global perspective on functional traits. J. Veg. Sci. 1999, 10, 621-630. [CrossRef]

25. Mabry, C.; Ackerly, D.; Gerhardt, F. Landscape and species-level distribution of morphological and life history traits in a temperate woodland flora. J. Veg. Sci. 2000, 11, 213-224. [CrossRef]

26. Cornelissen, J.H.C.; Lavorel, S.; Garnier, E.; Diaz, S.; Buchmann, N.; Gurvich, D.E.; Reich, P.B.; Ter Steege, H.; Morgan, H.D.; Van Der Heijden, M.G.A.; et al. A Handbook of protocols for standardised and easy measurement of plant functional traits worldwide. Aust. J. Bot. 2003, 51, 335-380. [CrossRef]

27. Barboni, D.; Harrison, S.P.; Bartlein, P.J.; Jalut, G.; New, M.; Prentice, I.C.; Sanchez-Goñi, M.F.; Spessa, A.; Davis, B.; Stevenson, A.C. Relationships between plant traits and climate in the Mediterranean region: A pollen data analysis. J. Veg. Sci. 2004, 15, 635-646. [CrossRef]

28. Faucon, M.P.; Houben, D.; Lambers, H. Plant functional traits: Soil and ecosystem services. Trends Plant Sci. 2017, 22, 385-394. [CrossRef] [PubMed]

29. Grime, J.P. Evidence for existence of three primary strategies in plants and its relevance to ecological and evolutionary theory. Am. Nat. 1977, 111, 1169-1194. [CrossRef]

30. Brown, C.; Lundholm, J. Microclimate and substrate depth influence green roof plant community dynamics. Landsc. Urban Plan. 2015, 143, 134-142. [CrossRef]

31. Petchey, O.L.; Gaston, K.J. Functional diversity: Back to basics and looking forward. Ecol. Lett. 2006, 9, 741-758. [CrossRef] [PubMed]

32. Xie, G.; Lundholm, J.T.; Maclvor, J.S. Phylogenetic diversity and plant trait composition predict multiple ecosystem functions in green roofs. Sci. Total Environ. 2018, 628-629, 1017-1026. [CrossRef] [PubMed]

33. Du, P.; Arndt, S.K.; Farrell, C. Relationships between plant drought response, traits and climate of origin for green roof plant selection. Ecol. Appl. 2018, 28, 1752-1761. [CrossRef]

34. Tatsuya, M.; Kazuaki, T.; Toshiya, O. Leaf traits of Sedum species used for green roofs and its influence on evapotranspiration. J. Jpn. Soc. Reveg. Technol. 2017, 43, 115-120.

35. Cook-Patton, S.C.; Bauerle, T.L. Potential benefits of plant diversity on vegetated roofs: A literature review. J. Environ. Manag. 2012, 106, 85-92. [CrossRef]

36. Hooper, D.U.; Chapin, F.S.; Ewel, J.J.; Hector, A.; Inchausti, P.; Lavorel, S.; Lawton, J.H.; Lodge, D.M.; Loreau, M.; Naeem, S. Effects of biodiversity on ecosystem functioning: A consensus of current knowledge. Ecol. Monogr. 2005, 75, 3-35. [CrossRef]

37. Isbell, F.; Calcagno, V.; Hector, A.; Connolly, J.; Harpole, W.S.; Reich, P.B.; Scherer-Lorenzen, M.; Schmid, B.; Tilman, D.; Van Ruijven, J. High plant diversity is needed to maintain ecosystem services. Nature 2011, 477, 199-202. [CrossRef] [PubMed]

38. Pinto, R.; de Jonge, V.N.; Marques, J.C. Linking biodiversity indicators, ecosystem functioning, provision of services and human well-being in estuarine systems: Application of a conceptual framework. Ecol. Indic. 2014, 36, 644-655. [CrossRef] 
39. Lundholm, J.; MacIvor, J.S.; Macdougall, Z.; Ranalli, M. Plant species and functional group combinations affect green roof ecosystem functions. PLoS ONE 2010, 5, e9677. [CrossRef]

40. Van Mechelen, C.; Van Meerbeek, K.; Dutoit, T.; Hermy, M. Functional diversity as a framework for novel ecosystem design: The example of extensive green roofs. Landsc. Urban Plan. 2015, 136, 165-173. [CrossRef]

41. CNC-DIVERSITAS. Advances in Biodiversity Conservation and Research in China; China Meteorological Press: Beijing, China, 2014.

42. Lundholm, J.T. Green roof plant species diversity improves ecosystem multi-functionality. J. Appl. Ecol. 2015, 52, 726-734. [CrossRef]

43. Getter, K.L.; Rowe, D.B. The role of extensive green roofs in sustainable development. HortScience 2006, 41, 1276-1285. [CrossRef]

44. Liang, M.X. Preliminary Studies on Plants Selection for Green Roofs in North of China. Ph.D. Thesis, Beijing Forestry University, Beijing, China, 2012. (In Chinese with English Abstract).

45. Zhang, J.; Hu, Y.H.; Li, H.Y.; Liu, Q.-H. Compounded technique of lightweight roof greening. J. Northwest For. Univ. 2007, 22, 194, (In Chinese with English Abstract).

46. Panayiotis, N.; Panayiota, T.; Ioannis, C. Soil amendments reduce roof garden weight and influence the growth rate of Lantana. HortScience 2003, 38, 618-622. [CrossRef]

47. Tian, Y.; Jim, C.Y. Factors influencing the spatial pattern of sky gardens in the compact city of Hong Kong. Landsc. Urban Plan. 2011, 101, 299-309. [CrossRef]

48. Zhou, W.W.; Wang, Y.; Han, L.J. Investigation on the selection of green roof plants in Beijing city. J. Anhui Agric. Sci. 2008, 36, 200-201, (In Chinese with English Abstract).

49. Zhao, M.Z. Study on Management System \& Countermeasure of the Roof Greening in Beijing. Master's Thesis, Beijing Forestry University, Beijing, China, 2010. (In Chinese with English Abstract).

50. Li, R.L. Current Status of Beijing Roof Greening; Beijing University of Technology: Beijing, China, 2012.

51. Beijing Municipal Bureau of Statistics. Beijing Statistical Yearbook 2018; China Statistics Press: Beijing, China, 2018.

52. Xu, Z.X.; Zhang, L.; Ruan, B.Q. Analysis on the spatio-temperol distribution of precipitation in Beijing. Arid Land Geogr. 2006, 29, 186-192, (In Chinese with English Abstract).

53. Lang, J.D.; Liu, Y.H.; Chang, W. Study on the origin of urban plants in built-up areas of Beijing. Chin. Bull. Bot. 2008, 25, 192-202, (In Chinese with English Abstract).

54. China Industry Research. Survey on the Current Situation of China's Roof Greening Market and Trend Analysis of Its Development Prospect 2019. 2019. Available online: http://www.cir.cn/2014-03/ WuDingLvHuaShiChangYuCeBaoGao.html (accessed on 6 June 2019). (In Chinese).

55. Qin, Q.C.; Hu, D.; Li, Y.Z.; Guo, Z. Numerical simulation of microclimate in Beijing typical residential area based on ENVI-met model. J. Meteorol. Environ. 2015, 31, 56-62.

56. Liu, B.J.; Wang, S.H.; Lu, F.; Wang, X.Y.; Jensen, M.B.; Zheng, S.W.; Liu, L.; Shan, M.Y.; Zhao, K.X. Roof greening in urban area of Bejing during 2005-2015: Development trends, distribution patterns and policy promotion. Chin. J. Ecol. 2018, 37, 1509-1517, (In Chinese with English Abstract).

57. He, S.Y.; Xing, Q.H.; Yi, X.T. Flora of Beijing (I); Revised in 1992; Beijing Press: Beijing, China, 1993. (In Chinese)

58. He, S.Y.; Xing, Q.H.; Yi, X.T. Flora of Beijing (II); Revised in 1992; Beijing Press: Beijing. China, 1993. (In Chinese)

59. Lundholm, J.; Heim, A.; Tran, S.; Smith, T. Leaf and life history traits predict plant growth in a green roof ecosystem. PLoS ONE 2014, 9, e101395. [CrossRef] [PubMed]

60. Diaz, S.; Hodgson, J.G.; Thompson, K.; Cabido, M.; Cornelissen, J.H.C.; Jalili, A.; Montserrat-Marti, G.; Grime, J.P.; Zarrinkamar, F.; Asri, Y. The plant traits that drive ecosystems: Evidence from three continents. J. Veg. Sci. 2004, 15, 295-304. [CrossRef]

61. Kühn, I.; Brandenburg, M.; Klotz, S. Why do alien plant species that reproduce in natural habitats occur more frequently? Divers. Distrib. 2004, 10, 417-425. [CrossRef]

62. Moles, A.T.; Falster, D.S.; Leishman, M.R.; Westoby, M. Small-seeded species produce more seeds per square metre of canopy per year, but not per individual per lifetime. J. Ecol. 2004, 92, 384-396. [CrossRef]

63. Kleyer, M.; Bekker, R.M.; Knevel, I.C.; Bakker, J.P.; Thompson, K.; Sonnenschein, M.; Poschlod, P.; Van Groenendael, J.M.; Klimeš, L.; Klimešová, J. The LEDA Traitbase: A database of life-history traits of the Northwest European flora. J. Ecol. 2008, 96, 1266-1274. [CrossRef] 
64. Kattge, J.; Knorr, W.; Raddatz, T.; Wirth, C. Quantifying photosynthetic capacity and its relationship to leaf nitrogen content for global-scale terrestrial biosphere models. Glob. Chang. Biol. 2009, 15, 976-991. [CrossRef]

65. Paula, S.; Arianoutsou, M.; Kazanis, D.; Tavsanoglu, Ç.; Lloret, F.; Buhk, C.; Ojeda, F.; Luna, B.; Moreno, J.M.; Rodrigo, A. Fire-related traits for plant species of the Mediterranean Basin: Ecological Archives E090-094. Ecology 2009, 90, 1420. [CrossRef]

66. Bai, C.Y.; Li, K.; Wei, F.C. The current state of roof greening in Pu'er city of Yunnan province. Trop. Agric. Sci. Technol. 2017, 40, 39-42, (In Chinese with English Abstract).

67. Huang, R.; Wu, Y.H.; Zhao, F. Present situation investigation and existing problem analysis of roof greening in Lanzhou city. J. Gansu For. Sci. Technol. 2016, 41, 41-45, (In Chinese with English Abstract).

68. Ai, L.J.; Feng, Y.L.; Tan, X.Y. Investigation and analysis of green roof in Chongqing. Chin. Landsc. Archit. 2015, 31, 27-30, (In Chinese with English Abstract).

69. Huang, W.C. Study on the Application of Sedums on Roof Garden in Shanghai. J. Anhui Agric. Sci. 2005, 33, 1041-1043, (In Chinese with English Abstract).

(C) 2019 by the authors. Licensee MDPI, Basel, Switzerland. This article is an open access article distributed under the terms and conditions of the Creative Commons Attribution (CC BY) license (http://creativecommons.org/licenses/by/4.0/). 